\title{
Pengembangan Game Edukasi Sebagai Media Pembelajaran Deret Bilangan di Sekolah Menengah Atas
}

\author{
I Md. Suka Maryana, I Md. Candiasa, Djoko Waluyo \\ Jurusan Pendidikan Matematika, Fakultas Matematika dan IImu Pengetahuan Alam \\ Universitas Pendidikan Ganesha \\ Singaraja, Indonesia
}

e-mail : mariosukasuka@gmail.com, candiasa@undiksha.ac.id, djoko.waluyo@undiksha.ac.id

\begin{abstract}
Abstrak
Penelitian ini bertujuan untuk 1) Mengembangkan desain game edukasi sebagai media pembelajaran deret bilangan di sekolah menengah atas, 2) Mengimplementasikan game edukasi sebagai media pembelajaran deret bilangan di sekolah menengah atas menggunakan aplikasi visual basic, 3) Mendeskripsikan tingkat kevalidan, kepraktisan, dan keefektifan game edukasi yang digunakan sebagai media dalam pembelajaran matematika. Jenis Penelitian ini adalah penelitian pengembangan. Model penelitian ini menggunakan model pengembangan Four $D$ (4D). Namun pada penelitian ini hanya sampai tahap Development. Populasi ini adalah seluruh siswa kelas XI IPA 3. Sebanyak 33 orang dipilih sebagai sampel yang ditentukan dengan teknik Purposive Samping, Data dikumpulkan dengan metode tes berbentuk pilihan ganda dan kuesioner. Hasil penelitian menunjukkan bahwa 1) Desain game edukasi sebagai media pembelajaran dalam penelitian ini disusun secara sederhana, jelas, dan memuat beberapa hal, antara lain: 1) 8 latihan agar siswa lebih memahami konsep deret tak hingga, 2) misi yang harus dipecahkan, sebanyak 3 misi yang pemecahannya menggunakan konsep deret tak hingga, 3) petunjuk penyelesaian baik latihan maupun misi, Game edukasi dibuat dengan aplikasi visual basic. 2) Implementasi game edukasi yaitu game edukasi diberikan kepada siswa kelas XI IPA 3 SMA N 2 Singaraja yang berjumlah 33 orang siswa sebagai uji coba terbatas. Siswa diminta memainkan game mengenai deret bilangan, kemudian mengisi kuesioner yang telah disiapkan serta menjawab soal tes yang telah diberikan. Begitu pula guru diberikan angket sebagai penilaian terhadap media game edukasi. 3) Multimedia pembelajaran yang dikembangkan telah diuji validitas, kepraktisan, dan keefektifannya. Hasil uji tersebut menyatakan bahwa multimedia pembelajaran yang dikembangkan memenuhi kriteria valid, praktis, dan efektif sehingga dapat diterima dan layak digunakan sebagai media pembelajaran pada materi deret bilangan.
\end{abstract}

Kata kunci : deret bilangan, game edukasi, visual basic

\begin{abstract}
This study aims to 1) Develop educational game design as a medium of learning series of series in high school, 2) Implement educational game as a medium of learning series of series in high school using visual basic applications, 3) Describe the level of validity, practicality, and effectiveness of games education used as a medium in learning mathematics. This type of research is a development study. This research model uses Four D (4-D) development model. But in this study only until Development stage. This population is all students of class XI IPA 3. A total of 33 people selected as a sample determined by Purposive Sampling technique, Data collected by multiple choice shaped test method and questionnaire. The result of the research shows that 1) The design of educational games as learning media in this study is arranged in simple, clear, and contains some things, among others: 1) 8 exercises so that students better understand the concept of the unending series, 2) the mission to be solved, as many as 3 missions solving using the concept of incomplete series, 3) instructions for completion of both exercise and mission, Educational games made with visual basic
\end{abstract}


applications. 2) Implementation of educational game that is educational game given to students of class XI IPA 3 SMA N 2 Singaraja amounting to 33 students as a limited trial. Students are asked to play games on a series of numbers, then fill in the prepared questionnaire and answer the test questions that have been given. Similarly, teachers were given a questionnaire as an assessment of educational game media. 3) The developed learning multimedia has been tested for validity, practicality, and effectiveness. The test results stated that the developed learning multimedia meets the valid, practical, and effective criteria so it is acceptable and feasible to be used as a learning series of numbers.

Key word : educational games, series of numbers, visual basic

\section{PENDAHULUAN}

Penggunaan multimedia $\begin{array}{r}\text { dapat } \\ \text { diimplementasikan dalam berbagai }\end{array}$
pembelajaran di kelas, salah satunya
dalam pembelajaran matematika.
Matematika merupakan salah satu mata
pelajaran yang dikenal sulit oleh para
peserta didik. Penggunaan multimedia
yang menarik dalam pembelajaran
matematika diharapkan dapat membuat
peserta didik lebih mudah memahami
materi dan mampu menumbuhkan motivasi
belajar peserta didik selama mengikuti
pembelajaran.

Pembelajaran matematika dengan multimedia juga dapat membantu dalam memvisualisasikan objek-objek yang sulit dibayangkan oleh peserta didik seperti objek-objek pada bahasan deret bilangan. Deret bilangan merupakan penjabaran dari pokok bahasan barisan dan deret tak hingga yang merupakan materi pokok siswa SMA Kelas XI. Setelah mempelajari materi deret bilangan siswa diharapkan memiliki pengalaman belajar, sebagai berikut. (1) Terlibat aktif dalam pembelajaran deret bilangan

Menemukan pola barisan dan deret. (3) Menjelaskan definisi barisan naik dan turun. Kenyataan yang ditemukan di lapangan, masih banyak siswa yang kurang paham dengan konsep deret bilangan sehingga pengalaman belajar yang mereka dapatkan masih kurang.

Sejalan dengan hal tersebut di atas, peneliti melakukan observasi dan wawancara dengan beberapa guru matematika SMA Kelas XI yang menerapkan Kurikulum 2013 terkait dengan pembelajaran matematika pada deret bilangan. Berdasarkan observasi dan wawancara tersebut diperoleh informasi bahwa rendahnya pemahaman konsep siswa disebabkan oleh beberapa faktor. Pertama, motivasi belajar siswa untuk mengikuti pelajaran masih rendah yang dapat diketahui dari kecenderungan siswa yang kurang aktif dalam pembelajaran. Siswa kurang mempersiapkan diri di rumah sebelum mengikuti pembelajaran di sekolah sehingga siswa hanya menunggu guru untuk memberikan penjelasan mengenai materi pembelajaran. Rendahnya motivasi belajar siswa juga terlihat dari rendahnya minat bertanya siswa mengenai materi yang belum sepenuhnya dipahami.

Kedua, siswa kurang banyak mengerjakan latihan soal terkait materi yang dipelajari. Siswa kebanyakan hanya mengerjakan soal-soal yang mudah dan cenderung tidak ingin mengerjakan soalsoal dengan tingkat kesukaran yang lebih tinggi. Padahal dengan mengerjakan latihan soal yang lebih banyak berguna untuk memperdalam pemahaman siswa terhadap materi yang dipelajari. Ketiga, ketersediaan sumber belajar terutama multimedia untuk penunjang pembelajaran yang masih terbatas. Guru dalam pembelajaran di kelas telah berupaya menyediakan multimedia berupa penggunaan slide power point, namun penggunaan multimedia tersebut masih kurang praktis dan efektif bagi siswa karena hanya berisikan paparan materi dan visualisasi objek geometri yang sederhana sehingga siswa kurang tertarik dalam mempelajarinya. Padahal dengan penggunaan multimedia pembelajaran yang menarik, praktis, dan efektif merupakan sarana untuk meningkatkan 
kualitas pendidikan di sekolah (Suprapto, 2006).

Berdasarkan pemaparan di atas, diperlukan adanya pengembangan multimedia yang lebih menarik dan mampu meningkatkan motivasi peserta didik untuk belajar. Salah satu multimedia yang dapat dimanfaatkan dan dikembangkan dalam pembelajaran adalah penggunaan game. Ketertarikan peserta didik akan game tampaknya memang tidak bisa dipungkiri dan bahkan mungkin saja akan terus bertambah dari waktu ke waktu. Dilihat dari kenyataan di lapangan menunjukkan bahwa peserta didik sering melupakan belajar karena waktu yang seharusnya untuk belajar dihabiskan dengan bermain game. Game memang memiliki dampak negatif bagi pemainnya, seperti membuat kecanduan hingga lupa dengan waktu. Akan tetapi, game juga memiliki dampak positif.

Melihat keadaan tersebut, diperlukan berbagai inovasi kreatif dalam menciptakan game yang dapat digunakan sebagai multimedia pembelajaran yang inovatif sehingga bisa dimanfaatkan di dunia pendidikan guna mendukung kegiatan pembelajaran dan menarik minat belajar peserta didik. Game yang dapat digunakan sebagai media pembelajaran dikenal dengan nama game edukasi. Game edukasi adalah game yang khusus dirancang untuk mengajarkan user (peserta didik) suatu pembelajaran tertentu, pengembangan konsep dan pemahaman, membimbing mereka dalam melatih kemampuan mereka, dan memotivasi mereka untuk memainkannya (Hurd dan Jenuings, 2009).

Game membuat siswa merasa senang dan nyaman dalam mengikuti pembelajaran (joyful learning). Bukan hanya menghindarkan dari kejenuhan dan rasa kantuk, kegiatan-kegiatan yang "heboh" dalam pembelajaran menggunakan game akan meninggalkan kesan yang lama dalam memori peserta didik serta memberikan peluang kepada siswa untuk belajar dengan suasana yang lebih menyenangkan tanpa meninggalkan tujuan pembelajaran (Rahmani, 2011). Pembelajaran dengan menggunakan game edukasi akan membuat siswa merasa bahwa aktivitas yang mereka lakukan adalah bermain game, tetapi sebenarnya mereka sedang belajar sesuatu yang telah direncanakan oleh guru.

Pembelajaran dengan menggunakan game edukasi dapat dilaksanakan di sekolah karena di beberapa sekolah sudah memiliki sarana dan prasarana yang memadai, seperti laboratorium komputer dan LCD proyektor. Dalam pembelajaran di kelas, peserta didik sudah pernah mengikuti pembelajaran menggunakan komputer di mana guru menyajikan materi dengan menggunakan media presentasi berupa slide power point. Hanya saja pelaksanaannya masih jarang karena keterbatasan media pembelajaran yang relevan dengan penggunaan komputer.

Berdasarkan uraian di atas, untuk mengatasi permasalahan siswa dalam pembelajaran matematika pada deret bilangan serta membantu guru dalam menyediakan multimedia yang menarik, peneliti merasa perlu untuk melaksanakan penelitian untuk mengembangkan multimedia game edukasi khususnya pada deret bilangan. Oleh karena itu peneliti mengajukan proposal penelitian yang berjudul "Pengembangan Game Edukasi Sebagai Media Pembelajaran Deret Bilangan di Sekolah Menengah Atas". Tujuan penelitian ini yaitu, 1) Mengembangkan desain game edukasi sebagai media pembelajaran deret bilangan di sekolah menengah atas. 2) Mengimplementasikan game edukasi sebagai media pembelajaran deret bilangan di sekolah menengah atas menggunakan aplikasi visual basic. 3) Mendeskripsikan tingkat kevalidan, kepraktisan, dan keefektifan game edukasi yang digunakan sebagai media dalam pembelajaran matematika.

\section{METODE}

Penelitian ini dilakukan dengan pendekatan penelitian dan pengembangan (research and development). Penelitian ini bertujuan untuk menghasilkan produk penelitian berupa multimedia game edukasi. Penelitian ini dirancang berdasarkan model penelitian dan pengembangan Four $D$ (4-D) yang dikembangkan oleh Thiagarajan (1974). 
Tahapan pengembangan model 4-D terdiri dari empat tahapan yang meliputi tahap pendefinisian (define), perancangan (design), pengembangan (develop) dan penyebaran (disseminate). Penelitian ini dilakukan sampai tahap pengembangan (develop) karena keterbatasan waktu, biaya, dan kemampuan dari peneliti.

Sampel ditentukan dengan Teknik purposive sampling. Dipilih siswa kelas XI IPA 3 SMA N 2 Singaraja sebagai sampel uji coba terbatas dengan jumlah 33 siswa.

Metode pengumpulan data penelitian ini adalah angket, tes dan observasi. Angket yang digunakan, yaitu angket validasi ahli materi, angket validasi ahli perangkat pembelajaran, angket respons peserta didik, dan angket respons guru. Indikator penilaian pada angket respons siswa dan guru menggunakan lima skala penilaian. Sedangkan indikator penilaian pada angket validasi ahli materi dan angket validasi ahli perangkat pembelajaran menggunakan tiga skala. Hasil dari angket validasi para ahli akan digunakan sebagai bahan pertimbangan terkait kelayakan multimedia yang dikembangkan sedangkan hasil dari angket respons siswa dan guru akan digunakan untuk mengetahui keterlaksanaan/kepraktisan dari multimedia yang dikembangkan. Sebelum digunakan, angket respons siswa dan respons guru diuji validitasnya melalui expert judgment, yaitu dua orang dosen di Jurusan Pendidikan Matematika Undiksha.

Instrumen tes hasil belajar Matematika berjumlah 25 butir soal mengenai deret tak hingga. Tes digunakan untuk mengumpulkan data tentang ketuntasan belajar peserta didik. Tes diberikan sekali di akhir pertemuan setelah peserta didik selesai memainkan game edukasi pada bahasan deret bilangan. Jenis tes yang digunakan adalah tes objektif yang berbentuk pilihan ganda. Tes pilihan ganda adalah tes yang meminta responden untuk mengisikan informasi yang belum lengkap yang terdapat dalam tes dengan memilih jawaban dari berbagai alternatif pilihan yang telah disediakan (Candiasa, 2010). Sebelum digunakan, tes tersebut terlebih dahulu diuji validitas isi melalui expert juggement, yaitu dua orang dosen di Jurusan Pendidikan Matematika
Undiksha yang mempunyai pengalaman dan pendidikan dalam menilai sebuah tes. Setelah dilakukan uji validitas isi maka diperoleh koefisien validitas isi sebesar 1,00 yang termasuk dalam kategori sangat tinggi. Oleh karena itu, dapat dikatakan bahwa tingkat validitas isi instrumen penelitian adalah sangat tinggi sehingga layak digunakan.

Sedangkan metode observasi digunakan untuk mengamati hal-hal yang tidak mampu direkam melalui alat pengumpulan data yang telah disediakan. Hal-hal yang diobservasi berkaitan dengan kejadian-kejadian yang terjadi selama pengimplementasian perangkat. Data yang diperoleh dari observasi ini digunakan untuk melengkapi data yang dikumpulkan dengan menggunakan lembar observasi.

Teknik analisis data dalam penelitian ini adalah analisis data deskriptif kualitatif dan analisis data deskriptif kuantitatif. Teknik analisis data deskriptif kualitatif digunakan untuk mengelola data hasil review ahli materi, ahli perangkat pembelajaran, dan respons peserta didik serta respons guru. Teknik analisis data ini dilakukan dengan mengelompokkan informasi-informasi dari data kualitatif berupa masukan, tanggapan, kritik, dan saran perbaikan yang terdapat pada angket. Hasil data ini kemudian digunakan untuk merevisi produk yang dikembangkan.

Teknik analisis data deskriptif kuantitatif digunakan untuk mengelola data hasil angket validasi, angket respons peserta didik, dan hasil tes. Hasil analisis data ini kemudian digunakan untuk mengetahui validitas, kepraktisan, dan efektivitas multimedia game edukasi yang dikembangkan. Multimedia game edukasi dikatakan memiliki kriteria baik jika memenuhi aspek validitas, kepraktisan, dan efektivitas.

\section{HASIL DAN PEMBAHASAN Hasil \\ Setelah melalui tahap pengembangan, dihasilkan suatu multimedia pembelajaran yang berbentuk game edukasi yang sudah dievaluasi. \\ Produk Multimedia Berbentuk Game Edukasi}


Multimedia berbentuk game edukasi yang dikembangkan merupakan media pembelajaran pada sub pokok deret bilangan yang berbentuk game berjenis petualangan. Game ini menceritakan tentang seorang "Agent Math" yang harus melewati rintangan dengan memecahkan permasalahan yang berhubungan dengan deret bilangan. Dalam petualangannya, "Agen Math" menghadapi berbagai tantangan untuk menyelesaikan misinya. Misi yang dihadapi mengenai deret tak hingga. Namun sebelum menyelesaikan misi, "Agen Math" harus melewati 8 pelatihan untuk lebih memahami konsep deret tak hingga. Setelah itu barulah "Agent Math" dapat menghadapi misinya. Tokoh "Agent Math" akan dimainkan oleh siswa. Siswa harus menjawab pertanyaan yang diberikan pada pelatihan mulai dari pelatihan 1 hingga pelatihan 8 . Penyelesaiannya dilakukan secara bertahap. Sebelum dapat menemukan jawaban pada pelatihan 1, siswa tidak dapat melanjutkan permainan pada pelatihan berikutnya.

Berikut akan diuraikan hal-hal yang dapat dilakukan siswa dalam menggunakan game yang dikembangkan. Pada bagian awal game terdapat intro yang menampilkan secara singkat tujuan dari pengembangan game. Setelah intro selesai, siswa akan langsung melihat tampilan menu game yang berisikan animasi tokoh utama dalam game dan beberapa tombol yang dapat dipilih oleh siswa untuk memainkan game seperti Gambar 1.

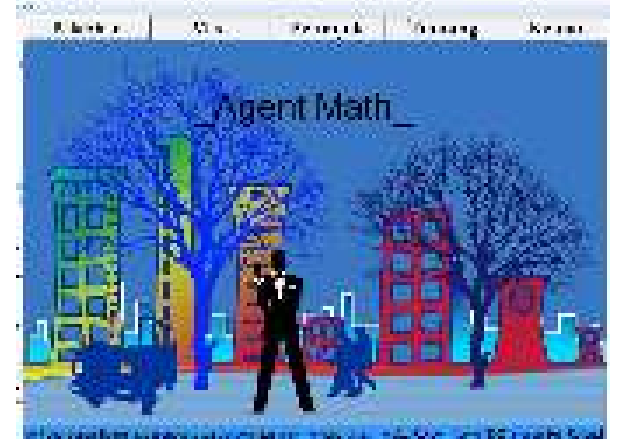

\section{Gambar 1. Tampilan Menu Game}

Pada menu tentang dapat dilihat identitas pembuat game

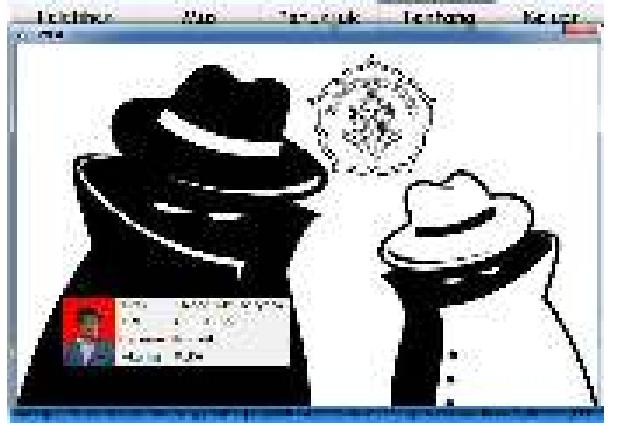

\section{Gambar 2. Tampilan Menu Tentang}

Sebelum memulai permainan, siswa diharapkan terlebih dahulu mengetahui petunjuk permainan dan navigasi yang digunakan dalam permainan yang terdapat pada menu Petunjuk. Untuk melihat menu Petunjuk siswa dapat mengklik tombol petunjuk dan akan tampil menu Petunjuk seperti Gambar 3.

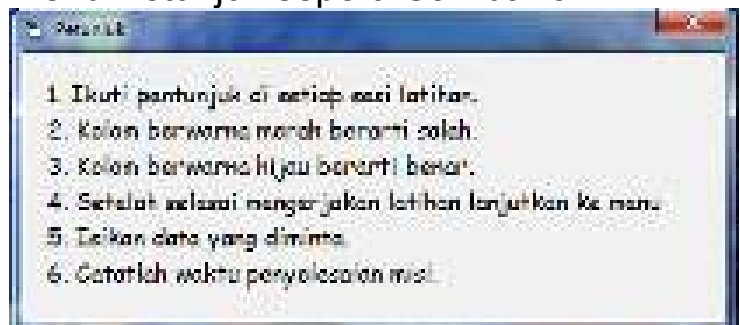

\section{Gambar 3. Tampilan Menu Petunjuk} Siswa dapat melanjutkan permainan dengan menjawab soal pada menu pelatihan yang terdiri dari 8 latihan. Setiap latihan harus diselesaikan satu per satu agar dapat melanjutkan pada pelatihan berikutnya. Latihan 1 dapat dilihat pada gambar 4. seperti berikut.

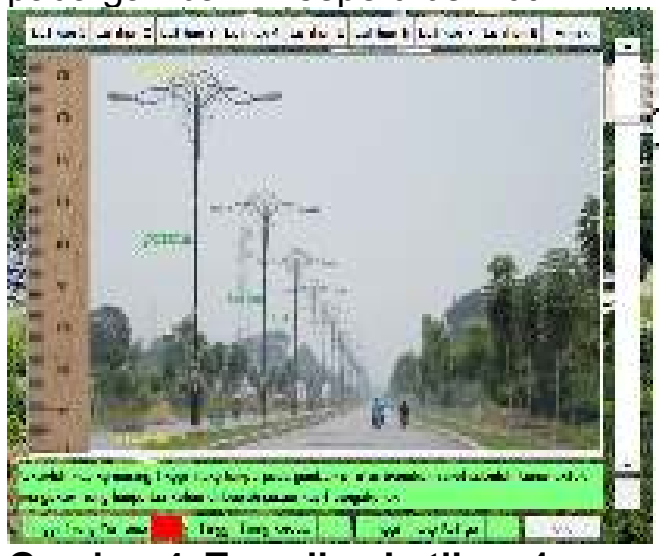

Gambar 4. Tampilan Latihan 1

Pada latihan 1 siswa diminta mengukur tinggi masing-masing tiang lampu, yang membentuk pola deret tak hingga. Siswa dapat mengisi kolom yang berwarna merah sesuai dengan ukuran tiang lampu. Apabila kolom sudah berubah menjadi warna hijau berarti ukurannya 
benar. Setelah selesai pada latihan 1, siswa mengklik tombol OK untuk dapat melanjutkan pada latihan 2. Tampilan latihan 2 dapat dilihat pada gambar 5 berikut ini.

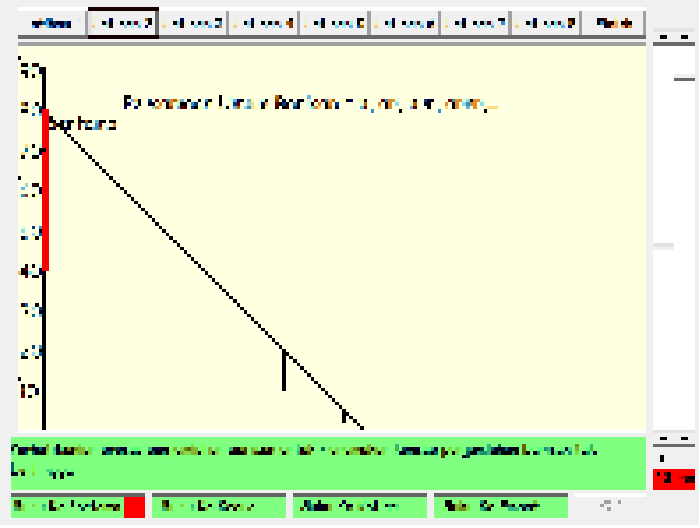

\section{Gambar 5. Tampilan Latihan 2}

Pada latihan 2 siswa diminta mengukur tinggi barisan seperti gambar 5 . Pengukuran dapat disesuaikan dengan menggerakkan skroll pada bagian kanan. Hasil pengukuran dapat dilihat pada bagian pojok kanan bawah. Hasil tersebut dapat dimasukkan ke dalam kolom merah. Hasil pengukuran yang benar akan terlihat pada perubahan warna kolom menjadi warna hijau. Apabila kolom jawaban masih berwarna merah, maka hasil pengukuran belum tepat. Setelah semua kolom jawaban berwarna hijau, siswa dapat mengklik tombol OK, kemudian muncul pola deret bilangan tak hingga sesuai hasil pengukuran. Permainan dilanjutkan pada latihan 3 seperti gambar 6 berikut ini.

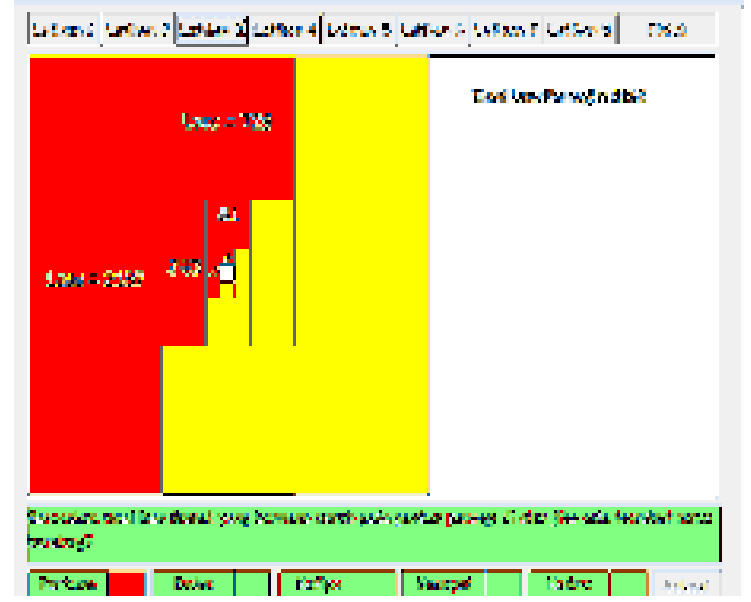

Gambar 6. Tampilan Latihan 3

Pada latihan 3, siswa diminta mengisi kolom jawaban dengan menghitung total luas daerah berwarna merah untuk menemukan jumlah deret tak hingga. Siswa dapat mengisikan kolom berwarna merah mulai dari ukuran luas pertama. Apabila kolom merah sudah berubah menjadi warna hijau berarti jawaban sudah benar, sehingga dapat dilanjutkan dengan pengukuran luas daerah kedua, begitu seterusnya hingga kolom kelima. Kemudian siswa mengklik tombol selesai untuk melanjutkan pada latihan 4. Tampilan latihan 4 dapat dilihat pada gambar 7 berikut ini.

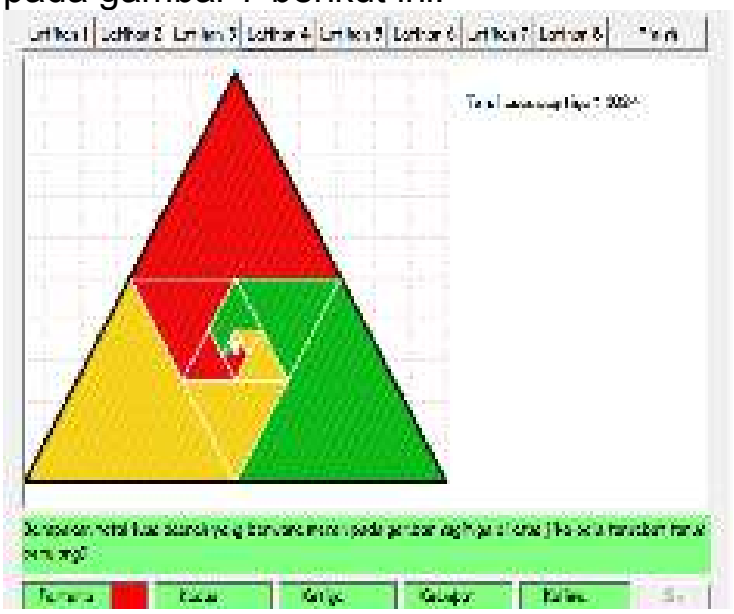

Gambar 7. Tampilan Latihan 4

Pada latihan 4 siswa diminta menghitung total luas daerah segitiga yang berwarna merah. Siswa mengisi kolom jawaban dengan menghitung luas tiap segitiga berwarna merah. Siswa dapat mengisi luas segitiga pertama sampai kelima. Kemudian siswa mengklik tombol OK, lalu akan muncul total luas segitiga. Setelah itu siswa dapat melanjutkan pada latihan 5. Tampilan latihan 5 dapat dilihat pada gambar 8 berikut ini.

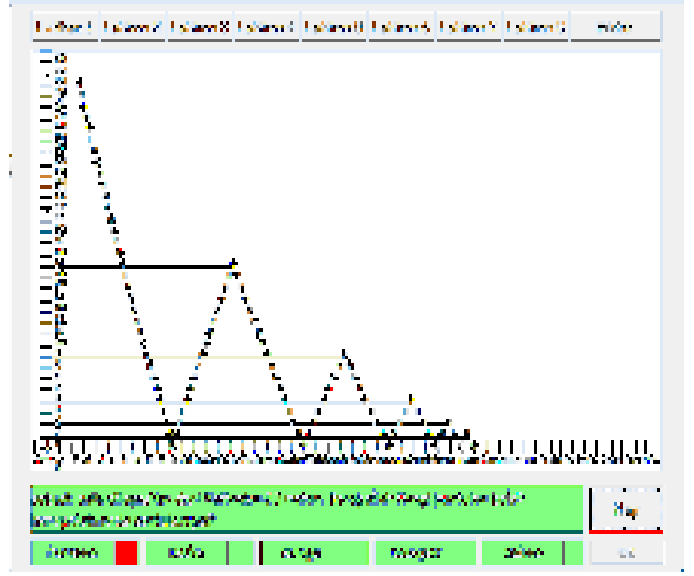

\section{Gambar 8. Tampilan Latihan 5}

Pada latihan 5 siswa harus mengklik tombol "play" terlebih dahulu untuk melihat ilustrasi pantulan bola. 
Kemudian siswa diminta mengukur tinggi pantulan bola serta menghitung rasionya. Tinggi pantulan bola dapat diukur dengan melihat garis horizontal merah pada puncak pantulan, kemudian melihat ukurannya. Siswa dapat mengisi mulai dari kolom merah pertama, sebagai tanda ukuran tinggi pantulan pertama. Apabila kolom merah berubah menjadi hijau maka jawaban benar. Begitu seterusnya hingga tinggi pantulan kelima. Setelah selesai siswa mengklik tombol OK, lalu muncul konsep deret tak hingga, khususnya dalam mencari rasio. Latihan selanjutnya adalah latihan 6 . Adapun tampilan latihan 6 dapat dilihat pada gambar 9 berikut ini.

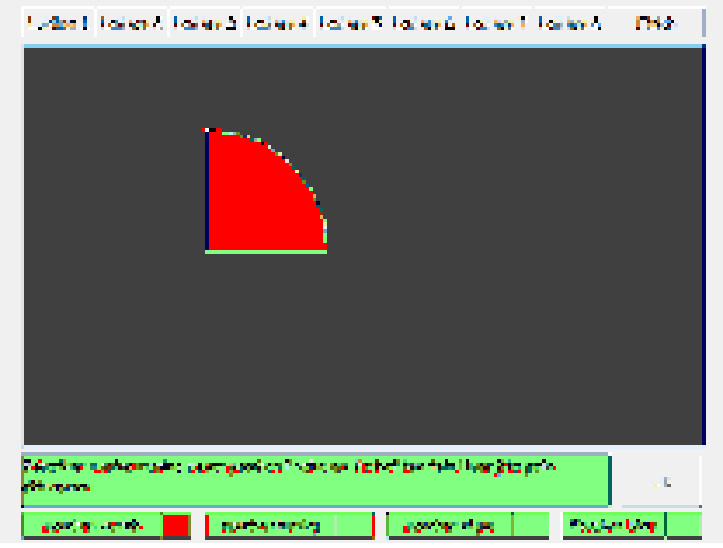

Gambar 9. Tampilan Latihan 6

Pada latihan 6 siswa diminta menyebutkan masing-masing ukuran pecahan lingkaran, kemudian menghitung total luasnya. Setelah mengisi ukuran masing-masing pecahan pada kolom jawaban, siswa mengklik tombol OK, kemudian muncul konsep jumlah deret tak hingga. Permainan dilanjutkan pada latihan 7. Tampilan latihan 7 dapat dilihat pada gambar 10 berikut ini.

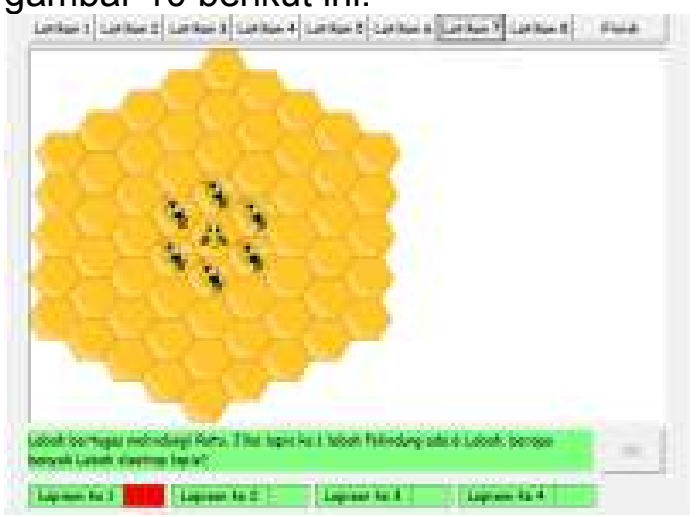

Gambar 10. Tampilan Latihan 7

Pada latihan 7 siswa diminta menghitung banyak lebah sebagai lapis pelindung Ratu. Semakin keluar lapisan akan bertambah mengikuti deret bilangan. Banyak lebah pada lapisan ke 1 dapat diisi pada kolom merah. Apabila kolom berubah menjadi berwarna hijau, maka jawaban benar. Selanjutnya dapat diisi jawaban lebah pelindung pada lapisan ke 2. Begitu seterusnya hingga lapisan ke 4 . Setelah selesai mengisi kolom jawaban, siswa mengklik tombol OK. Kemudian permainan dilanjutkan dengan latihan 8. Tampilan latihan 8 dapat dilihat pada gambar $11 \mathrm{di}$ bawah ini.

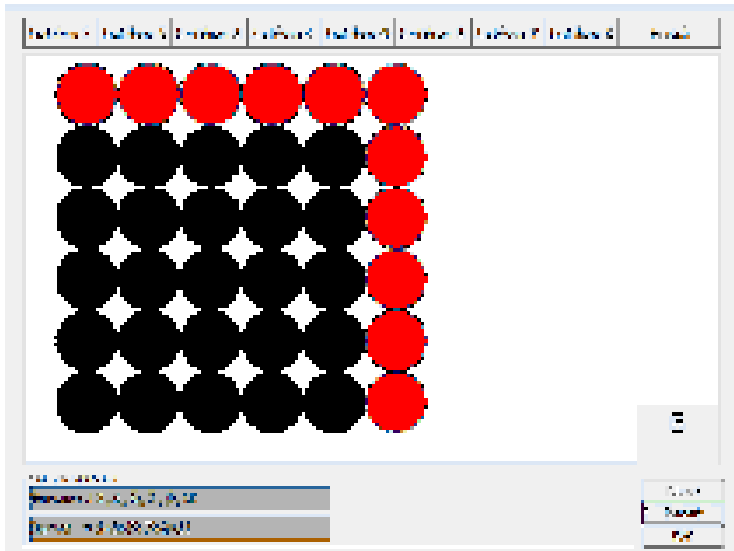

\section{Gambar 11. Tampilan Latihan 8}

Pada latihan 8, siswa menghitung jumlah lingkaran merah yang terus bertambah tiap lapisnya, dengan terlebih dahulu mengklik tombol "play". Kemudian siswa dapat melihat konsep barisan dan deret berdasarkan jumlah lingkaran merah. Setelah menyelesaikan 8 latihan, siswa mengklik "Finish". Setelah itu, siswa bisa melanjutkan permainan pada misi "Agent Math". Untuk dapat masuk pada menu misi, siswa harus memasukkan namanya sebagai "Agent Math", kemudian mengklik OK seperti pada gambar 12 berikut ini.

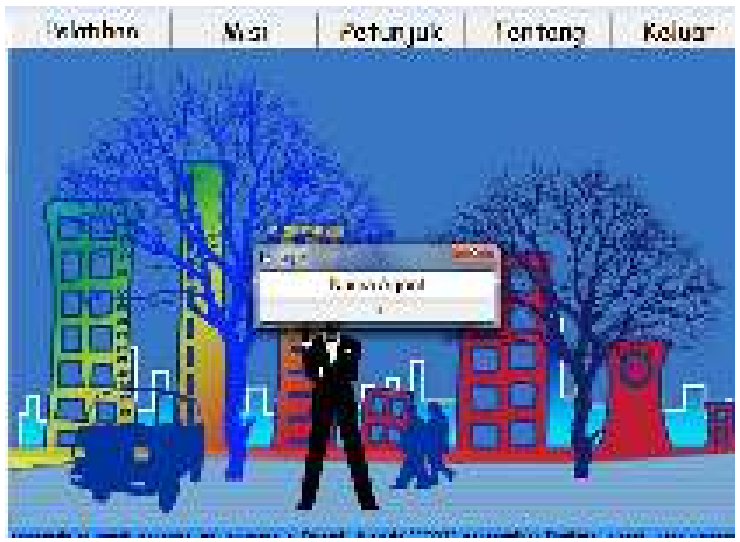




\section{Gambar 12. Tampilan Awal Misi Agent Math}

Setelah mengisi nama "Agent Math", siswa dapat memulai misi 1. Pada misi 1 , siswa yang dalam hal ini sebagai "Agent Math", ditugaskan untuk mencari nomor kursi pada tempat duduk target yang sedang menonton di bioskop. Untuk dapat menjawab nomor kursi, "Agent Math" harus menggunakan prinsip barisan bilangan. Setelah mendapatkan hasil, "Agent Math" dapat melanjutkan pada misi 2 dengan mengklik ikon "Ikuti" seperti pada gambar 13 berikut ini.

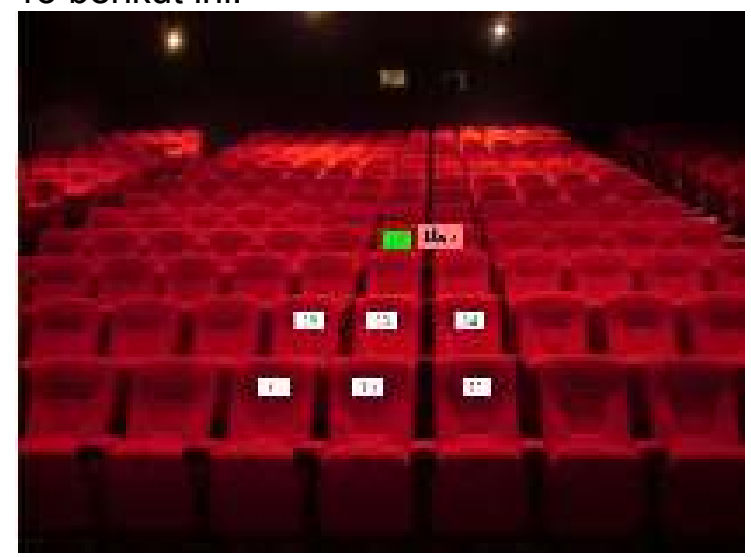

Gambar 13. Tampilan Misi 1 yang Sudah Terpecahkan

Setelah mengklik ikon "Ikuti", "Agent Math" dapat melanjutkan permainan pada misi 2. Pada Misi 2, "Agent Math" harus menghitung jaraknya dengan target yang diikuti, agar target tidak mencurigai bahwa dirinya sedang diikuti. Untuk dapat menghitung jarak "Agent Math" dengan target, sebelumnya "Agent Math" dapat mengklik ikon "Lihat" untuk dapat melihat ukuran yang diperlukan untuk dapat menghitung jarak "Agent Math" dengan target, seperti gambar 14 berikut ini.

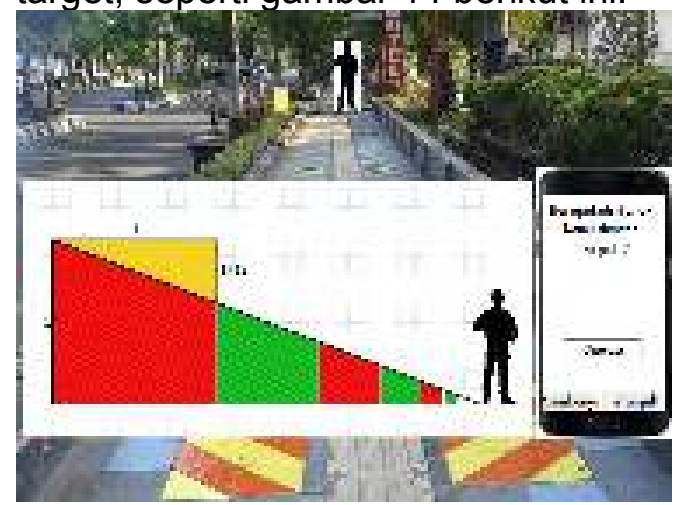

Gambar 14. Tampilan Ikon "Lihat" pada Misi 2
"Agent Math" menghitung jaraknya dengan target, kemudian memasukkan hasilnya pada kolom jawaban. Jawaban benar apabila kolom jawaban berubah warna menjadi hijau. Langkah selanjutnya klik ikon "ikuti” seperti gambar 15 berikut ini.

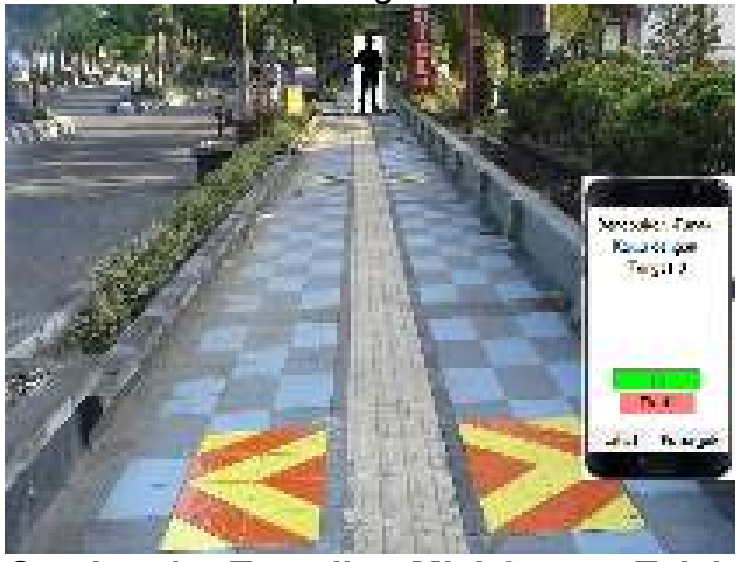

Gambar 15. Tampilan Misi 2 yang Telah Terpecahkan

Dengan diperolehnya jarak "Agent Math" dengan target, Misi 2 pun selesai. "Agent Math" melanjutkan misi 3 sekaligus misi terakhir yang harus dipecahkan. Pada misi 3 "Agent Math" diminta untuk membuka peti harta karun menggunakan pola deret. "Agent math" harus membuka peti harta karun dengan mencari bentuk kunci yang tepat dengan menerapkan prinsip deret bilangan, seperti pada gambar 16 berikut ini.

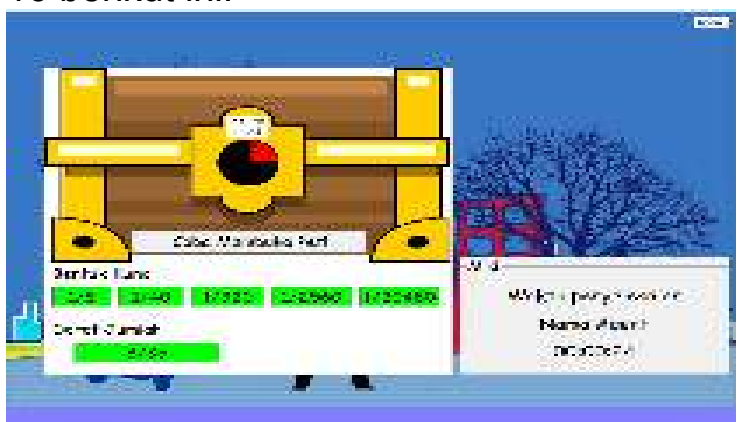

\section{Gambar 16. Tampilan Misi 3 yang Sudah Terpecahkan}

Siswa pada bagian akhir game yang berhasil membuka peti harta karun menggunakan pola deret tak hingga menunjukkan bahwa permainan telah selesai. Lama waktu menjawab dalam misi akan terlihat pula pada akhir game ini. Untuk mengakhiri permainan siswa dapat mengklik ikon "home" pada pojok kanan atas tampilan game. Pada tampilan "home" siswa mengklik menu "keluar" untuk dapat keluar dari permainan/game. 


\section{Kualitas Produk Multimedia Berbentuk Game Edukasi \\ Validitas Multimedia Berbentuk Game Edukasi}

Hasil uji validitas oleh ahli perangkat pembelajaran yaitu rata-rata skor ahli I sebesar 2,8 sedangkan ahli II sebesar 2,7. Jadi rata-rata skor kedua ahli 27,5 . Hasil tersebut menunjukkan bahwa multimedia game edukasi berkategori valid. Berdasarkan hasil tersebut menunjukkan bahwa game edukasi yang dikembangkan masuk dalam kriteria layak atau valid. Ahli perangkat 1 memberikan komentar bahwa game edukasi yang dikembangkan sudah bagus dan sudah layak dipakai untuk membantu siswa memahami materi deret bilangan. Ahli perangkat 2 memberikan komentar bahwa game edukasi yang dikembangkan sudah sesuai dengan materi.

Hasil uji validitas oleh ahli materi yaitu rata-rata skor ahli I sebesar 2,7, sedangkan rata-rata skor ahli II sebesar 2,8 . Jadi rata-rata skor kedua ahli 2,75 . Hal ini menunjukkan bahwa game edukasi yang dikembangkan masuk dalam kriteria layak atau valid. Ahli materi 1 memberikan komentar bahwa game edukasi yang dikembangkan sudah bagus dan sesuai dengan materi deret tak hingga. Sedangkan ahli materi 2 memberikan komentar bahwa game edukasi yang dikembangkan akan sangat mendukung dalam pembelajaran untuk mengaitkan materi yang terdapat dalam buku siswa dan dapat mengarahkan siswa untuk contoh yang lebih abstrak.

Kepraktisan game edukasi yang dikembangkan dalam penelitian ini dilihat dari skor angket respons siswa dan angket respons guru terhadap game edukasi yang diambil di bagian akhir kegiatan uji coba. Hasil angket respons siswa terhadap multimedia game edukasi memperoleh rata-rata skor sebesar 4,24 dengan kriteria sangat tinggi. Oleh karena itu dapat dikatakan bahwa game edukasi yang dikembangkan memiliki kepraktisan sangat tinggi. Hasil angket respons guru terhadap multimedia game edukasi memperoleh skor rata-rata sebesar 4,25 yang termasuk dalam kriteria sangat tinggi. Oleh karena itu, dapat dikatakan bahwa game edukasi yang dikembangkan memiliki kepraktisan sangat tinggi.

Keefektifan multimedia pembelajaran dalam penelitian ini dilihat berdasarkan ketercapaian tujuan pembelajaran menggunakan multimedia pembelajaran yang dikembangkan. Penilaian keefektifan multimedia pembelajaran dalam penelitian ini diperoleh melalui tes. Hasil tes matematika menunjukkan bahwa rata-rata skor sebesar 79,33 dengan nilai tertinggi 96 dan nilai terendah 52. Sehingga dapat dikatakan multimedia pembelajaran yang dikembangkan memenuhi kriteria efektif untuk digunakan sebagai media pembelajaran karena ketuntasan klasikal siswa adalah $88 \%$ lebih besar dari ketuntasan klasikal yang ditetapkan, yaitu $85 \%$.

\section{Pembahasan \\ Desain Game Edukasi Sebagai Media Pembelajaran Deret Bilangan Di Sekolah Menengah Atas}

Game edukasi ini dibuat dengan aplikasi Visual Basic. Game edukasi ini terdiri dari enam menu yaitu menu Pelatihan, Misi, Petunjuk, Tentang, dan Keluar. Cerita dalam game menceritakan tentang "Agent Math" (yang dimainkan oleh siswa) yang harus memecahkan misi. Sebelum memecahkan misi, "Agent Math" harus melewati 8 latihan mengenai konsep deret tak hingga, agar memudahkan penyelesaian misi. Adapun latihan 1 siswa diminta mengukur tinggi tiang listrik yang berjajar membentuk suatu pola deret tak hingga. Kemudian pada latihan 2 siswa diminta mengukur garis yang panjangnya membentuk suatu pola deret tak hingga. Pada latihan 3 siswa diminta menghitung total I luas daerah yang berwarna merah, untuk menemukan konsep jumlah deret tak hingga. Pada latihan 4 siswa diminta menghitung luas segitiga merah yang membentuk pola deret tak hingga. Pada latihan 5, siswa diminta mengukur tinggi pantulan bola yang membentuk pola deret tak hingga. Pada latihan 6 , siswa diminta menyebutkan masing-masing ukuran pecahan lingkaran, kemudian menghitung total luasnya. Pada latihan 7 siswa diminta 
menghitung banyak lebah sebagai lapis pelindung Ratu dengan menggunakan konsep jumlah deret tak hingga. Pada latihan 8 siswa diminta menghitung jumlah lingkaran merah, yang bertambah tiap lapisnya. Untuk semua latihan, baik latihan 1 sampai latihan 8 menggunakan konsep deret tak hingga dalam penyelesaiannya. Setelah menyelesaikan 8 latihan, barulah siswa bisa melanjutkan permainan untuk menyelesaikan misi "Agent Math".

Ada 3 misi yang harus dipecahkan "Agent Math". Misi pertama "Agent Math" harus bisa menemukan nomor tempat duduk target yang sedang menonton film di bioskop dengan menggunakan prinsip deret tak hingga. Misi kedua, "Agent Math" harus mengukur jarak yang tepat dengan target agar tidak dicurigai oleh target bahwa "Agent Math" sedang mengikutinya. Untuk dapat menghitung jarak yang tepat, maka "Agent Math" harus menggunakan konsep deret tak hingga. Sedangkan misi ketiga, "Agent Math" melihat target masuk ke suatu tempat, dan ternyata target memiliki peti harta karun yang disimpan, namun ia belum bisa membukanya. Akhirnya "Agent Math" memunculkan diri dan menawarkan diri untuk dapat membuka peti harta karun tersebut. Untuk dapat membuka peti harta karun, "Agent Math" harus menggunakan konsep deret tak hingga.

Pembelajaran dengan multimedia berbentuk game edukasi ini membantu mengarahkan siswa untuk menemukan konsep deret tak hingga sehingga diharapkan pada akhirnya siswa dapat memahami konsep deret tak hingga dengan lebih baik. Hal senada dikemukakan oleh Wahyono (dalam Hikam, 2013) bahwa multimedia memiliki kelebihan dalam menjelaskan suatu konsep yaitu dapat menuntut siswa untuk bereksplorasi dan menganalisis, mencoba dan menggali konsep dan prinsip yang termuat dalam suatu materi yang dihadapinya.

\section{Implementasi Game Edukasi sebagai Media Pembelajaran Deret Bilangan di Sekolah Menengah Atas}

"Game Edukasi Agent Math" diberikan kepada siswa kelas XI SMA N 2 Singaraja. Siswa yang dipilih adalah siswa kelas XI IPA 3 berjumlah 33 orang. Siswa memainkan game sesuai petunjuk yang ada pada game. Game dimulai dengan menyelesaikan 8 latihan, kemudian siswa memecahkan 3 misi "Agent Math" sesuai konsep deret tak hingga. Berdasarkan pemantauan secara umum saat siswa memainkan game edukasi, terlihat siswa sangat tertarik dalam memainkan game edukasi ini. Meskipun masih ada beberapa siswa yang bertanya mengenai pengoperasian game, namun secara keseluruhan siswa dapat memainkan game dengan baik. Game edukasi membuat siswa antusias dalam belajar Matematika terutama belajar mengenai materi tentang deret tak hingga. Hal ini dibuktikan dengan hasil kuesioner respons siswa, di mana siswa memberikan komentar bahwa game edukasi lebih memudahkan pemahaman materi deret bilangan, dibandingkan media tulis. Menurut siswa menggunakan multimedia hanya mengandalkan logika dan sudah disiapkan rumus-rumusnya sehingga lebih mudah mengerjakan soal yang diberikan. Selain itu, siswa mengatakan bahwa dengan adanya multimedia game edukasi, pembelajaran menjadi lebih menarik dan tidak membosankan, bahkan ada salah satu komentar siswa yang mengatakan bahwa dengan adanya media game edukasi membuat siswa menjadi lebih tertarik untuk mempelajarinya. Namun secara keseluruhan, multimedia game edukasi meningkatkan minat belajar matematika siswa. Kelayakan media dalam pembelajaran Matematika juga dibuktikan dengan hasil angket respons siswa yang memperoleh rata-rata 4,24 dengan kriteria sangat tinggi. Begitu juga angket respons guru memperoleh rata-rata 4,25 dengan kriteria sangat tinggi. Berdasarkan hasil tersebut maka media game edukasi sangat tepat diterapkan dalam pembelajaran Matematika khususnya pada materi deret bilangan. Keberhasilan penerapan multimedia game edukasi juga dibuktikan dengan hasil tes siswa yang menunjukkan rata-rata 79,33 dengan ketuntasan klasikal $88 \%$. Hal ini menunjukkan bahwa implementasi game edukasi pada siswa sekolah menengah atas sangat tepat diterapkan dalam pembelajaran 
Matematika khususnya materi deret bilangan.

\section{Tingkat Kevalidan, Kepraktisan, dan Keefektifan Game Edukasi yang Digunakan sebagai Media dalam Pembelajaran Matematika}

Berdasarkan hasil uji kevalidan, kepraktisan, dan keefektifan game edukasi diperoleh hasil multimedia valid, praktis, dan efektif. Berdasarkan hasil perhitungan diperoleh hasil bahwa multimedia layak, praktis dan efektif.

Secara umum selama kegiatan uji coba terhadap kelompok siswa, pembelajaran berlangsung secara menyenangkan dan lebih menarik karena siswa dapat belajar sambil bermain. Hal ini diperkuat dengan pendapat Ariani dan Haryanto (2010) mengenai manfaat penggunaan multimedia dalam pembelajaran yaitu proses pembelajaran menjadi lebih menarik, lebih interaktif, jumlah waktu mengajar (ceramah) dapat dikurangi, siswa dapat lebih termotivasi dan terdongkrak, pembelajaran dapat dilakukan di mana dan kapan saja (sangat fleksibel), serta sikap dan perhatian belajar siswa dapat ditingkatkan dan dipusatkan.

Selain untuk mengetahui kepraktisan game edukasi yang dikembangkan, kegiatan uji coba terbatas juga bertujuan untuk mengetahui keefektifan game edukasi yang dikembangkan. Kriteria keefektifan dari game edukasi yang dikembangkan dalam penelitian ini berkaitan dengan ketuntasan hasil belajar siswa secara klasikal. Keefektifan game edukasi ini diketahui dari nilai tes.

Hasil analisis nilai tes yang diperoleh siswa menunjukkan bahwa ketuntasan klasikal sebesar $88 \%$ dengan jumlah siswa yang tuntas sebanyak 29 siswa dari 33 siswa. Siswa yang belum tuntas diduga karena rendahnya aktivitas siswa dalam pembelajaran sehingga motivasi siswa rendah dan juga bisa disebabkan siswa belum terbiasa menggunakan game edukasi dalam pembelajaran yang mengharuskan siswa untuk menemukan suatu konsep sendiri sehingga menyebabkan prestasi yang dicapai belum optimal dan perlu waktu untuk penyesuaian. Berdasarkan ketuntasan klasikal siswa maka dapat disimpulkan bahwa game edukasi yang dikembangkan efektif digunakan dalam pembelajaran.

Berdasarkan hasil evaluasi para ahli dan hasil kegiatan uji coba maka multimedia berbentuk game edukasi yang dikembangkan sudah dapat digunakan sebagai multimedia pembelajaran matematika dengan sub pokok deret tak hingga pada siswa kelas XI SMA N 2 Singaraja. Multimedia ini dapat digunakan baik oleh siswa maupun guru dalam tatap muka di kelas atau dapat pula digunakan di luar pembelajaran di sekolah. Game edukasi ini diharapkan dapat membantu siswa belajar sub materi deret tak hingga secara mandiri maupun secara berkelompok.

\section{Simpulan dan Saran}

Berdasarkan pembahasan yang telah diuraikan dapat disimpulkan beberapa hal sebagai berikut. 1) Desain game edukasi memuat beberapa hal, antara lain: a) 8 latihan agar siswa lebih memahami konsep deret tak hingga, b) misi yang harus dipecahkan, sebanyak 3 misi yang pemecahannya menggunakan konsep deret tak hingga, c) petunjuk penyelesaian baik latihan maupun misi, Game edukasi dibuat dengan aplikasi visual basic. 2) Implementasi game edukasi yaitu game edukasi diberikan kepada siswa kelas $\mathrm{XI}$ IPA 3 SMA N 2 Singaraja yang berjumlah 33 orang siswa sebagai uji coba terbatas. Siswa diminta memainkan game mengenai deret bilangan, kemudian mengisi kuesioner yang telah disiapkan serta menjawab soal tes yang telah diberikan. 
Begitu pula guru diberikan angket sebagai penilaian terhadap media game edukasi. 3) Multimedia pembelajaran yang dikembangkan telah diuji validitas, kepraktisan, dan keefektifannya. Hasil uji tersebut menyatakan bahwa multimedia pembelajaran yang dikembangkan memenuhi kriteria valid, praktis, dan efektif sehingga dapat diterima dan layak digunakan sebagai media pembelajaran pada materi deret tak hingga.

Berdasarkan hasil penelitian yang telah diperoleh dapat disarankan beberapa hal sebagai berikut. 1) Guru disarankan untuk memanfaatkan multimedia pembelajaran yang dikembangkan sebagai penunjang pembelajaran berbasis komputer sehingga proses pembelajaran lebih bervariasi. 2) Siswa disarankan untuk menggunakan multimedia pembelajaran yang dikembangkan sebagai media untuk belajar materi deret bilangan. Dengan digunakannya multimedia pembelajaran yang dikembangkan, siswa akan mendapatkan pengalaman belajar yang baru dan menarik. 3) Peneliti lain yang tertarik melanjutkan penelitian ini, dapat mengembangkan multimedia supaya dapat merekam pengalaman atau aktivitas belajar siswa saat menggunakan multimedia. 4) Penelitian ini dilakukan sampai uji coba terbatas. Peneliti lain yang tertarik disarankan untuk melakukan penelitian dengan lingkup yang lebih luas, misalnya melakukan penelitian eksperimen sebagai uji coba media.

\section{DAFTAR RUJUKAN}

Candiasa, I Made. 2010. Pengujian Instrumen Penelitian Disertai Apikasi ITEMAN dan BIGSTEPS. Singaraja: Undiksha Press.

Hurd, D. and E. Jenuings. 2009. Standardized Educational Games Rating: Suggested Criteria. Tersedia pada http://www.scribd.com/doc/164454 10/Educational-Game-Ratings (diakses tanggal 30-10-2015).

Rahmani, Nani Sy. 2011. Pengajaran Cerdas dengan Joyful Learning. Tersedia pada http://www.bppk.kemenkeu.go.id/b erita-medan/12041-pengajarcerdas-dengan-joyful-learning (diakses tanggal 26 November 2015).

Suprapto, Tommy. 2006. Pengantar Teori Komunikasi. Cetakan Pertama, Yogyakarta: Media Pressindo.

Thiagarajan, Semmel and Semmel. 1974. Instructional Development for Training Teachers of Exceptional Children: A Sourcebook. Indiana: Indiana University. 